\title{
HUMAN INFECTION BY Angiostrongylus costaricensis IN VENEZUELA: FIRST REPORT OF A CONFIRMED CASE
}

\author{
Renzo Nino INCANI(1), Eduardo CALEIRAS(2), Milena MARTín(2) \& Carlos GONZÁLEZ(2)
}

\begin{abstract}
SUMMARY
A proven case of human infection caused by Angiostrongylus costaricensis is reported for the first time in Venezuela. The patient was a 57-year-old female surgically operated because of signs of peritonitis with a palpable mass at the lower right quadrant of the abdomen. WBC count reported 16,600 cells $/ \mathrm{mm}^{3}$, with $46 \%$ eosinophils. The tumoral aspect of ileocolic area and peritoneal lymph nodes prompted the resection of a large area of the terminal ileum, cecum, part of the ascending colon and a small part of the jejunum, where a small lesion was found. The pathology showed thickened areas of the intestinal wall with areas of hemorrhage and a perforation of the cecum. Histology showed intense eosinophil infiltration of the whole intestinal wall, granulomas with giant cells and eosinophils. Some of the granuloma surrounded round or oval eggs with content characterized by a large empty area, cells or embryo in the center, and sometimes nematode larvae. A cross section of an adult nematode worm was observed inside a branch of mesenteric artery. The intestinal affected area, the characteristics of the lesions, the presence of eggs in the submucosa with nematode larvae inside, and the observation of a nematode inside a mesenteric artery, makes sufficient criteria for the diagnosis of an infection by Angiostrongylus costaricensis.
\end{abstract}

KEYWORDS: Angiostrongylus costaricensis; Abdominal angiostrongyliasis; Eosinophilia, Eosinophilic ileocolitis; Venezuela.

\section{INTRODUCTION}

MORERA \& CÉSPEDES (1971) described Angiostrongylus costaricensis causing an abdominal eosinophilic ileocolitis as a new human disease. Several cases are asymptomatic or show light symptoms. However, in cases showing severe symptoms, the disease is often characterized by acute abdominal pain related to lesions in the ileocolic region, with presence of intense eosinophilia, eosinophilic infiltration of the intestinal wall, eggs in the submucosa and nematodes in the mesenteric arteries. Complications such as occlusive syndrome, peritonitis due to intestinal perforation, ulcers and hemorrhage, may occur. Ectopic localizations in the liver ${ }^{16}$ and in the spermatic cord in small boys ${ }^{21}$ have been also described. Man is an accidental host for this zoonotic infection. Although the parasite reaches an advanced degree of maturation in man, with the presence of adult worms and embrionated eggs in tissues, eggs or larvae are incapable of reaching the intestinal lumen. Consequently, the parasite cycle is not completed in humans. However, the complete life cycle ${ }^{15}$ takes place in the normal definitive hosts, usually rodents, and molluscs, the intermediate host. Larvae in the intestinal lumen of rats reach the soil where they are ingested by slugs or terrestrial snails. Within the intermediate host, larvae reach the infective third stage $\left(\mathrm{L}_{3}\right)$. When rodents ingest the intermediate host or contaminated food, the infective larvae penetrate the intestinal wall and migrate through blood/lymphatic vessels to the heart, lungs, heart again and arterial circulation to reach the mesenteric arteries. There, the juveniles $\left(\mathrm{L}_{5}\right)$ grow to maturity, lay eggs in the vessels that migrate to the intestinal wall ${ }^{19}$. First stage larvae $\mathrm{L}_{1}$ develop within eggs and, after hatching, they move to the intestinal wall toward the lumen. Humans are infected accidentally by the ingestion of pieces of slugs/snails or their mucous secretions left in uncooked vegetables and fruits. Although most cases have been reported in Costa Rica (up to 600 cases per year) ${ }^{18}$, the disease has been reported from the USA to Argentina, some Caribbean islands ${ }^{18}$, and in Zaire ${ }^{2}$. The first outbreak of the infection was reported from Guatemala9. In Venezuela, two cases were reported from surgical specimens of the ileocecal region, diagnosed as pseudo-tumoural eosinophilic ileocolitis of parasite origin, since nematode-type parasite structures were observed, but no diagnostic compromises were made ${ }^{28}$. In this paper, we report the first proven case of this infection in Venezuela and review the specific literature.

\section{MATERIAL AND METHODS}

Patient: The patient was a 57-year-old female Yugoslav-born Venezuelan, with almost her entire life living in Venezuela. She was admitted to hospital because of acute abdominal pain. Symptoms began four months before admission with pain at the lower chest, evaluated by a cardiologist, who did not find evidences of cardiac lesions. Three months before admission, she had pain at the lower abdominal quadrants with irradiation to lumbar regions, receiving symptomatic treatment, without amelioration of symptoms. The day of admission she had an acute pain at the hypogastrium and lower right quadrant (LRQ), weight loss of $10 \mathrm{~kg}$ in four months, with no fever. The physical examination

(1) Departamento de Parasitología, Facultad de Ciencias de la Salud, Universidad de Carabobo.

(2) Hospital Metropolitano del Norte, Valencia, Venezuela.

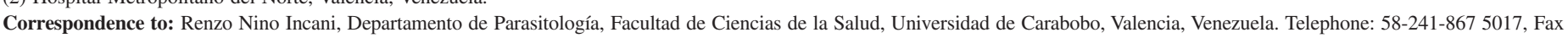
58-241-843 1938. E-mail: rincani@uc.edu.ve. 
showed a painful mass at the LRQ with characteristics of an acute abdomen. The diagnostic presumptions were: a) malignancy of the colon because of her age and 2) acute appendicitis.

Laboratory: Data three weeks before admission. A) Hematology: $\mathrm{Hb} 12.6 \mathrm{~g} / \mathrm{dL}, \mathrm{Ht} 38.7 \%$, WBC 13,600, granulocytes $77.3 \%\left(10,500 / \mathrm{mm}^{3}\right)$, MID cells $10.1 \%\left(1,400 / \mathrm{mm}^{3}\right)$ (no eosinophil count was available), lymphocytes $12.6 \%\left(1,700 / \mathrm{mm}^{3}\right)$, platelets $190,000 / \mathrm{mm}^{3}$, erythrocyte sedimentation rate (ESR) $50 \mathrm{~mm} / \mathrm{h}$ (normal $<16 \mathrm{~mm} / \mathrm{h}$ ). B) Urine: normal. C) Feces: absence of eggs or cysts. Blood chemistry: glucose, cholesterol, triglycerides, HDL-cholesterol and LDL-cholesterol, within normal values. Data at the time of admission. A) Hematology: Hb $11.8 \mathrm{~g} / \mathrm{dL}, \mathrm{Ht} 36.7 \%$, WBC $16,600 / \mathrm{mm}^{3}$, neutrophils $40 \%\left(6,640 / \mathrm{mm}^{3}\right)$, eosinophils $46 \%$ $\left(7,636 / \mathrm{mm}^{3}\right)$, lymphocytes $8.0 \%\left(1,328 / \mathrm{mm}^{3}\right)$, monocytes $6.0 \%(996 /$ $\mathrm{mm}^{3}$ ), platelets $208,000 / \mathrm{mm}^{3}$, ESR $61 \mathrm{~mm} / \mathrm{h}$ (normal $<20 \mathrm{~mm} / \mathrm{h}$ ). B) Urine: normal. C) Feces: absence of eggs or cysts. D) Blood chemistry: glucose, creatinin within normal values. E) Prothrombin time and partial thromboplastine time normal. F) VDRL and HIV 1-2 negatives. G) Aspartate aminotransferase (AST) and alanine aminotransferase (ALT) normal, alkaline phosphatase (AlkP) 176 U/L (ref. 50-136). H) Electrolytes: $\mathrm{Na}, \mathrm{K}, \mathrm{Cl}, \mathrm{Ca}, \mathrm{Mg}$ normal

$\mathrm{X}$ ray simple of the abdomen: Abundant pneumofaecal intracolonic material.

Abdominal and pelvic ultrasound: Important intestinal distension was observed, with a target-type round image in the LRQ. With this picture, an urgent exploratory laparotomy was performed.

Informed consent: Informed consent was obtained from the patient for publication of her case.

\section{RESULTS}

Surgery: Abdominal surgery revealed the presence of a mass at the ileo-cecal region with tumoral aspect and partial necrosis of the cecum. Two small tumors were observed in the ileum (at 50 and $80 \mathrm{~cm}$ from the ileo-cecal valve) and another in a segment of jejunum $(30 \mathrm{~cm}$ from duodenum). Mesenteric lymph nodes were enlarged. A tumoral lesion six $\mathrm{cm}$ diameter was observed in the right hepatic lobe. With the intra-operatory presumption of malignancy, the cecum-appendix was resected, together with adjacent ileum including the lesions, $20 \mathrm{~cm}$ of the adjacent ascending colon, and a $7 \mathrm{~cm}$ segment around the lesion of jejunum. An end to end ileo-colic anastomosis was performed, without trans- or post-operatory complications.

Pathology: a. Macroscopic. Dark brown thickened areas were seen in the surface of the resected area of the ileum and cecum, with thickening of the whole intestinal wall. The cecum was perforated. b. Microscopic. Biopsies of cecum, and the areas of the colon, ileum and jejunum resected and stained with HE showed extensive eosinophil infiltration of the whole intestinal wall, with giant cells and granulomas. Eggs of a nematode, round-oval shape, regular shell, with ample empty space inside and embryo (Fig. 1) or nematode larvae (Fig. 2) at the center were seen, mainly in the submucosa. They measured 47.6 $( \pm 9.1) \times 36.5( \pm 6.4) \mu \mathrm{m}(\mathrm{n}=$ seven individual egg sections $)$. Transversal sections of an adult nematode worm, with typical external cuticle, muscle layers, pseudoceloma and internal organs, measuring
$251( \pm 29) \times 127( \pm 15) \mu \mathrm{m}$ in diameter $(\mathrm{n}=$ four sections of the same worm), were seen inside a mesenteric arterial vessel (Fig. 3), as well as fibrinoid material. Mesenteric and pericolonic lymph nodes with non-specific follicular reactive hyperplasia were also observed.

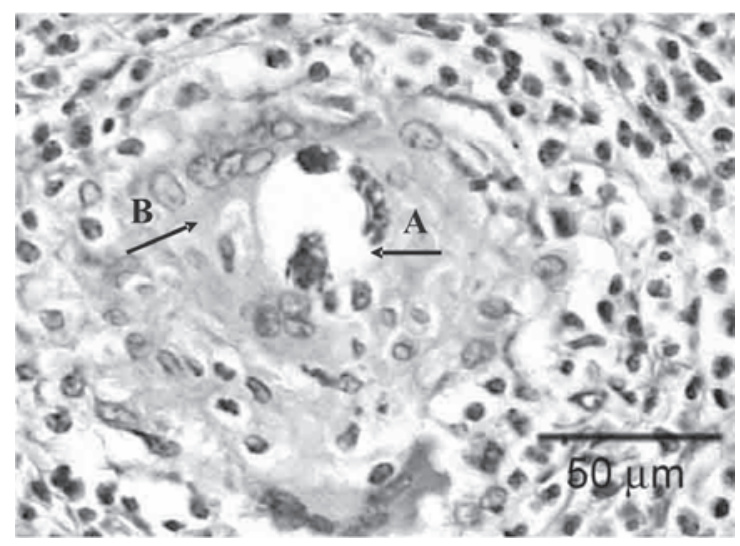

Fig. 1 - Section of the cecum (x 252) stained with HE. An egg of Angiostrongylus costaricensis with an embryo inside is seen in the submucosa, surrounded by a granulomatous reaction. $A$, egg. $B$, giant cell

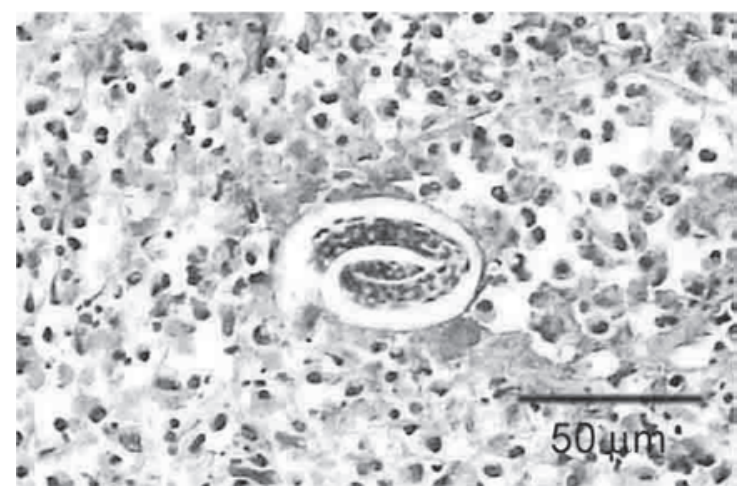

Fig. 2 - Section of the cecum (x 252) stained with HE. An egg of Angiostrongylus costaricensis with a larva inside is seen in the submucosa, surrounded by inflammatory cells (mostly eosinophils).

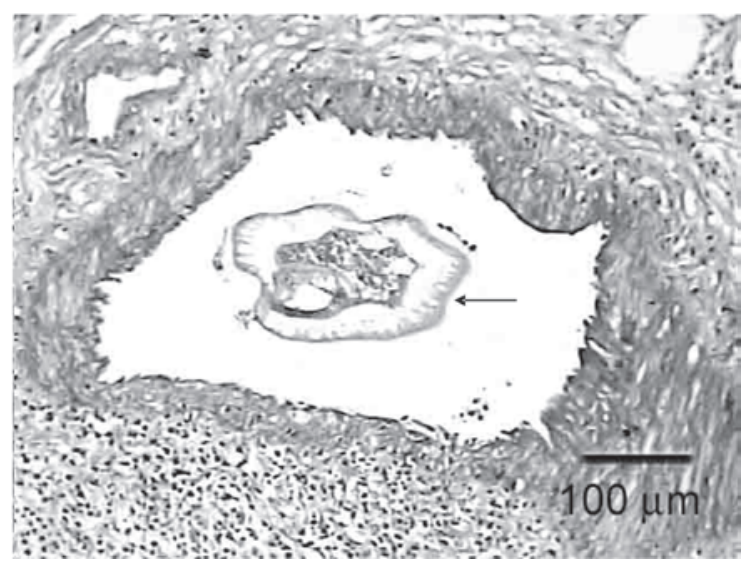

Fig. 3 - Transversal section of a mesenteric artery (x 63) stained with PAS, with an adult Angiostrongylus costaricensis inside $(\rightarrow)$. 
Patient evolution: Clinical. Up to two months post-surgery the patient had a good clinical recovery. Abdominal pain disappeared, weight loss stopped at $50 \mathrm{~kg}$ (66 kg before beginning of disease) and diet had to be suggested for the treatment of digestive disturbances related to the intestinal excised area. Laboratory one week after surgery. A) Blood chemistry: Total proteins, albumin and globulins, uric acid normal. B) Blood enzymes: AlkP and lactate dehydrogenase (LDH) normal, AST 74 U/L (ref < 40), ALT 85.9 U/L (ref. < 38), Glutamyl transferase $77 \mathrm{u} / \mathrm{L}$ (ref. 8-35). C) Others: $\mathrm{C}$ reactive protein (CRP) 1.2 $\mathrm{mg} / \mathrm{dL}$ (ref. < 0.6), B2 microglobulin normal. Laboratory one month after surgery. A) Hematology: Hb 12.4 g/dL, Ht 37.0\%, WBC 5,300/ $\mathrm{mm}^{3}$, neutrophils $43 \%\left(2,279 / \mathrm{mm}^{3}\right)$, Eosinophils $14 \%\left(742 / \mathrm{mm}^{3}\right)$, lymphocytes $30 \%\left(1,590 / \mathrm{mm}^{3}\right)$, monocytes $13 \%\left(689 \mathrm{~mm}^{3}\right)$, ESR 7.3 $\mathrm{mm} / \mathrm{h}$. B) Blood enzymes: AlkP, AST, ALT normal. C) Qualitative CRP: negative. Abdominal ultrasound one week after surgery. A hypoecogenic rounded area 5-cm diameter was detected in the right lobe of the liver. Abdominal CT scan one week after surgery. Round hypodense image $3 \times 4 \times 3.5 \mathrm{~cm}$ was observed in the right lobe of the liver, with similar characteristics after the administration of i.v. contrast. Abdominal CT scan seven weeks after surgery. Hypodense image previously observed in the liver is no longer detectable.

Epidemiology: The patient is a city dweller of Valencia, Venezuela, from middle upper class. Most of the ingested vegetables come from supermarkets, but she recalls the ingestion of garden vegetables or fruits (reported as carefully washed) and water from a farm of her property, visited only, but constantly, on weekends. Water contacts with rivers of the Venezuelan schistosomiasis endemic zone were reported in the childhood and adolescence, but the serology for schistosomiasis (circumoval precipitin test) carried out two weeks after surgery was negative.

\section{DISCUSSION}

This is the first proven case of a human infection by A. costaricensis in Venezuela. In a previous report of two cases of eosinophilic ileitis of parasitic origin from Venezuela ${ }^{28}$, no attempts were made to reach the specific diagnosis of the etiologic agent. However, on actual review of the paper, it was clear that both were infections by A. costaricensis. On retrospective, our case was classical in the way that it presented an ileo-colitis with eosinophilia, with a painful mass at the lower right quadrant associated with peritonitis and weight loss. Malignancy of lower digestive tract was the initial diagnosis, but appendicular peritonitis could not be ruled out, as it happens in many surgical cases of this disease. Histopathology of the lesions, however, met the criteria for the diagnosis of angiostrongyliasis as suggested by others ${ }^{6}$. These are: eosinophilic infiltration of all layers of the intestinal wall, granulomatous reaction, and eosinophilic necrotic angeitis. The presence of nematodes in the mesenteric arteries and eggs of the parasite in the submucosa fulfilled the diagnosis.

Abdominal angiostrongyliasis is a zoonotic infection that cannot be easily diagnosed clinically, unless an epidemiological situation of transmission has been detected previously. This is the case of Costa Rica, where hundreds of cases have been detected and the public health system is aware of the problem. The infection cannot be diagnosed in humans using parasitological methods, because man is an abnormal host, and no parasite forms are eliminated in the feces. Attempts at diagnosing the disease by serology have been made with some success ${ }^{5,7}$. DNA probes using PCR-RFLP that differentiate species of the genus Angiostrongylus are been developed ${ }^{4}$, and a PCR in sera for diagnosis has been attempted ${ }^{22}$.

Knowledge on the ecology and transmission has improved over the years. Rodents of 12 species (mostly the cotton rat Sigmodon hispidus) have been demonstrated as definite natural host, but also marmosets (Sanguinus mystax) ${ }^{23}$ and coatis (Nasua narica) ${ }^{13}$ have been found naturally infected. The dog has also been found naturally infected ${ }^{1}$ and experiments suggest that the dog may be a good reservoir host ${ }^{20}$. Veronicellid slugs have been found as intermediate hosts, as well as some species of terrestrial snails ${ }^{18}$. A rate of $50 \%$ of slugs were found naturally infected in several ecosystems in Costa Rica ${ }^{18}$. Such high rates of slug infection can make transmission easier than expected for a supposedly rare zoonosis. Our patient visits regularly a small farm, drinks water from a well and sometimes consumes locally grown garden vegetables and fruits, which may have been a source of infection.

In spite of all these developments in basic knowledge of the biology and transmission, very little improvements have been made in chemotherapy. Clinical attempts lack good controls, and clinical as well as parasitological criteria for cure are not easy to establish ${ }^{10}$, especially knowing that the infection may probably be self limited in most human cases. Experimental chemotherapy trials have been made with thiabendazole and albendazole ${ }^{17}$, and a wide array of traditional known antihelminthics including avermectin, ivermectin, santonin, milbemycin D, mebendazole, albendazole, thiabendazole, flubendazole, pyrantel, diethylcarbamazine, piperazine, biothionol, niclosamide, levamisole, as well as new yet undisclosed compounds like PF1022A, on both $A$. cantonensis and A. costaricensis, with variable effects, either on larval or adult stages ${ }^{11}$. It is suggested from this review, that flubendazole, pyrantel and PF1022A, could be considered candidates for human trials. Human treatment attempts have been hampered by the fear of parasite migrations and worsening of lesions as reported in some experiments with DEC, or mebendazole ${ }^{24}$. However, others did not find adult worm ectopic migration induced by mebendazole in mice ${ }^{12}$. It is clear that chemotherapy should be improved, and attempts with drugs such as the last three mentioned, should be made for the treatment of a disease that can be fatal. Finally, angiostrongyliasis should be placed in the differential diagnosis in cases of ileitis or ileo-colitis, where the biopsy shows eosinophil infiltration and histopathological signs of inflammatory response to live agent. This is true not only for people living in, but also for those travellers to and from the neotropics ${ }^{3,25,26,27}$.

\section{RESUMEN}

\section{Infección humana por Angiostrongylus costaricensis en Venezuela: primer reporte de un caso confirmado}

Un caso comprobado de infección humana por Angiostrongylus costaricensis es reportado para la literatura por vez primera en Venezuela. El paciente fue una mujer de 57 años de edad intervenida quirúrgicamente debido a signos de peritonitis, con una masa palpable en la fosa ilíaca derecha del abdomen. El recuento de leucocitos reportó 16.600 células/ $\mathrm{mm}^{3}$ con $46 \%$ eosinófilos. El aspecto tumoral del área íleocólica y las adenopatías peritoneales encontradas motivó la resección de un área grande del ileon terminal, ciego, parte del colon ascendente y una pequeña parte del yeyuno donde se encontró una pequeña lesión interpretada 
como metastásica. La patología mostró áreas engrosadas de la pared intestinal con zonas de hemorragia y perforación del ciego. El estudio histológico mostró una intensa infiltración eosinofílica de toda la pared intestinal, granulomas con células gigantes y eosinófilos. Algunos de los granulomas rodeaban huevos ovales o redondos con un contenido caracterizado por una gran área vacía, células o embriones en el centro, y en algunos casos una larva de nematodo. Un corte transversal de un verme nematodo adulto se observó dentro de una arteria mesentérica. El área intestinal afectada, las características de las lesiones, la presencia de huevos en la submucosa con larvas de nematodo dentro, y la observación de un nematodo dentro de una arteria mesentérica, aportan suficientes criterios para el diagnóstico de una infección por Angiostrongylus costaricensis.

\section{ACKNOWLEDGEMENTS}

We wish to acknowledge the following personnel of the Hospital Metropolitano del Norte, Valencia, Venezuela: Dr. Angela Pasi for the evaluation of the tomography and ultrasonography images, and Histotechnologists Mirlan Remanton and Elsa Escalona for the histological processing of the tissues. Thanks also to Prof. Pedro Morera, Universidad de Costa Rica, for helpful criticism and advice.

\section{REFERENCES}

1. ARROYO, R.; RODRÍGUEZ, F. \& BERROCAL, A. - Angiostrongilosis abdominal en Canis familiaris. Parasit. al Día, 12: 181-185, 1988.

2. BAIRD, J.K.; NEAFIE, R.C.; LANOIE, L. \& CONNOR, D.H. - Abdominal angiostrongylosis in an African man: case study. Amer. J. trop. Med. Hyg., 37; 353-356, 1987

3. BITAR, M.; STRAUCHEN, J.A.; SEQUEIRA, R.J. \& WU, M. - A case of lower gastrointestinal bleeding and small bowel tumorous masses. Arch. Path. Lab. Med., 129: $800-802,2005$.

4. CALDEIRA, R.L.; CARVALHO, O.S.; MENDONÇA, C.L.F.G. et al. - Molecular differentiation of Angiostrongylus costaricensis, A. cantonensis, and A. vasorum by polymerase chain reaction-restriction fragment length polymorphism. Mem. Inst. Oswaldo Cruz, 98: 1039-1043, 2003.

5. GEIGER, S.M.; LAITANO, A.C.; SIEVERS-TOSTES, C. et al. - Detection of the acute face of abdominal angiostrongyliasis with a parasitic-specific $\mathrm{IgG}$ enzyme linked immunosorbent assay. Mem. Inst. Oswaldo Cruz, 96: 515-518, 2001.

6. GRAEFF-TEIXEIRA, C.; CAMILO-COURA, L. \& LENZI, H.L. - Histopathological criteria for the diagnosis of abdominal angiostrongyliasis. Parasit. Res., 77: 606611, 1991.

7. GRAEFF-TEIXEIRA, C.; GOULART, A.H.M.; BRUM, C.O. et al. - Longitudinal clinical and serological survey of abdominal angiostrongyliasis in Guaporé, southern Brazil, from 1995 to 1999. Rev. Soc. bras. Med. trop., 38: 310-315, 2005.

8. ISHII, A.I.; TERADA, M.; FUJIU, Y. \& SANO, M. - In vivo efficacy of levamisole against larval stages of Angiostrongylus cantonensis and A. costaricensis. Southeast Asian J. trop. Med. publ. Hlth, 20: 109-117, 1989.

9. KRAMER, M.H.; GREER, G.J.; QUIÑONEZ, J.F. et al. - First reported outbreak of abdominal angiostrongyliasis. Clin. infect. Dis., 26: 365-372, 1998.

10. LORIA-CORTES, R. \& LOBO-SANAHUJA, J.F. - Clinical abdominal angiostrongyliasis. A study of 116 children with intestinal eosinophilic granuloma caused by Angiostrongylus costaricensis. Amer. J. trop. Med. Hyg., 29: 538-544, 1980.
11. MENTZ, M.B. \& GRAEFF-TEIXEIRA, C. - Drug trials of human angiostrongyliasis. Rev. Inst. Med. trop. S. Paulo, 45: 179-184, 2003.

12. MENTZ, M.B.; GRAEFF-TEIXEIRA, C. \& GARRIDO, C.T. - Treatment with mebendazole is not associated with distal migration of adult Angiostrongylus costaricensis in the murine experimental infection. Rev. Inst. Med. trop. S. Paulo, 46: 73-75, 2004.

13. MONGE, E.; ARROYO, R. \& SOLANO, E. - A. new definitive host of Angiostrongylus costaricensis (Morera and Céspedes, 1971). J. Parasit., 64: 34, 1978.

14. MORERA, P. \& CÉSPEDES, R. - Angiostrongylus costaricensis n. sp. (Nematoda Metastrongyloidea), a new lungworm occurring in man in Costa Rica. Rev. Biol. trop., 18: 173-185, 1971.

15. MORERA, P. - Life history and redescription of Angiostrongylus costaricensis Morera and Cespedes, 1971. Amer. J. trop. Med. Hyg., 22: 613-621, 1973.

16. MORERA, P.; PÉREZ, F.; MORA, F. \& CASTRO, L. - Visceral larva migrans-like syndrome caused by Angiostrongylus costaricensis. Amer. J. trop. Med. Hyg., 31: 67-70, 1982.

17. MORERA, P. \& BONTEMPO, I. - Acción de algunos antihelmínticos sobre Angiostrongylus costaricensis. Rev. Med. Hosp. nac. Niños (Costa Rica), 20: 165 174, 1985.

18. MORERA, P. - Abdominal angiostrongyliasis. In: STRICKLAND G.T., ed. Hunter's tropical medicine and emerging infectious diseases. 8. ed. Philadelphia, W.B. Saunders, 2001. p. 795-797.

19. MOTA, E.M. \& LENZI, H.L. - Angiostrongylus costaricensis: complete redescription of the migratory pathways based on experimental Sigmodon hispidus infection. Mem. Inst. Oswaldo Cruz, 100: 407-420, 2005.

20. RODRÍGUEZ, R.; AGOSTINI, A.A.; PORTO, S.M. et al. - Dogs may be a reservoir hos for Angiostrongylus costaricensis. Rev. Inst. Med. trop. S. Paulo, 44: 55-56, 2002.

21. RUIZ, P.J. \& MORERA, P. - Spermatic artery obstruction caused by Angiostrongylus costaricensis Morera and Céspedes, 1971. Amer. J. trop. Med. Hyg., 32: 1458$1459,1983$.

22. SILVA, A.C.; GRAEFF-TEIXEIRA, C. \& ZAHA, A. - Diagnosis of abdomina angiostrongyliasis by PCR from sera of patients. Rev. Inst. Med. trop. S. Paulo, 45: 295-297, 2003.

23. SLY, D.L.; TOFT, J.D.; GARDINER, G.H. \& LONDON, W.T. - Spontaneous occurrence of Angiostrongylus costaricensis in marmosets (Saguinus mystax). Lab. anim. Sci., 32: 286-288, 1982.

24. TERADA, M.; KINO, H.; AKYOL, C.V. \& SANO, M. - Effects of mebendazole on Angiostrongylus costaricensis in mice with special reference to the timing of treatment. Parasit. Res., 79: 441-443, 1993.

25. VAZQUEZ, J.J.; BOILS, P.L.; SOLA, J.J. et al. - Angiostrongyliasis in a European patient: a rare cause of gangrenous ischemic enterocolitis. Gastroenterology, 105: 1544$1549,1993$.

26. VUONG, P.N.; BRAMA, P.; BONETE, R. et al. - Necrotic eosinophilic angiitis with ileal perforation and peritonitis secondary to abdominal angiostrongyliasis. Presse méd., 31: 1700-1703, 2002.

27. WU, S.S.; FRENCH, S.W. \& TURNER, J.A. - Eosinophilic ileitis with perforation caused by Angiostrongylus (Parastrongylus) costaricensis: a case study and review. Arch. Path. Lab. Med., 121: 989-991, 1997.

28. ZAMBRANO, Z.; DÍAZ, P. \& SALFELDER, K. - Ileocolitis seudotumoral eosinofílica de origen parasitario. GEN (Venezuela), 29: 87-96, 1975.

Received: 20 February 2006

Accepted: 27 October 2006 